\title{
TEACHING VOCABULARY USING DIRECT METHOD AT SEVENTH GRADE OF JUNIOR HIGH SCHOOL
}

\author{
Gunawan Awan Sinaga ${ }^{1}$, Anisa Nur Safitri ${ }^{2}$ Efransyah $^{3}$ \\ ${ }^{1}$ IKIP Siliwangi \\ ${ }^{2}$ IKIP Siliwangi \\ ${ }^{3}$ IKIP Siliwangi \\ ${ }^{1}$ awansinaga23@gmail.com, ${ }^{2}$ anursafitri7@gmail.com, ${ }^{3}$ efransbae@ gmail.com
}

\begin{abstract}
Mastering vocabulary is very important, because vocabulary is the main aspect in teaching English. Vocabulary is a set of words for which an individual can assign meanings when he or she listening, speaking, reading or writting. People interact in communication will not be effective if they do not master the vocabulary. Direct method is one of method that can help learner to learn vocabulary by themselves. The objective of this research is to find out whether teaching vocabulary using direct method can improve students' vocabulary at seventh grade of MTs. Negeri Sukasari. The method of this research was quantitative method. The researchers used one group pretest-posttest design. The population of this research was the seventh grade students of MTs. Negeri Sukasari Cimahi and the sample taken from 31 students. The data of this research were collected by giving pretest and posttest, and the data was assisted by SPSS 23.version. Mean score of pretest was 71.61, while mean score of posttest was 89.68 and Wilcoxon test Asymp. Sig. (2-tailed) significant level was .000. In the other words, the null hypothesis (Ho) was rejected, because the Asymp. Sig. (2-tailed) in Wilcoxon test .000 was lower than 0.05 . It means that teaching using direct method can improve the students' vocabulary.
\end{abstract}

Keywords: Teaching, Vocabulary, Direct Method

\section{INTRODUCTION}

Language is very important for human, because human need language for communication to other people. According to Sapir as cited in (Kaswan \& Suprijadi, 2011) language is " a purely human and non-instructive method of communicating ideas, emotion and desires by means of a system of voluntarily produce symbols". There are many languages in the world especially in Indonesia which consist of various regional languages, also have to understand English.

Learning English is very important, because English is as one of foreign language. A lot of countries in the world used English as their second language, this phenomenon makes many countries add English language into their education curriculum to facilitate international link in communication, commerce, economy, politics, education, science, technology, and many others.

In Indonesia the most people used their local language as first language and Indonesian language as second language, English as foreign language which is taught in each level of school in our countries. English is taughts in every single students, from primary school until secondary school it refers to curriculum 2013 compulsory student to learn it. Therefore student hope simple technique to increase their ability in English.

Teaching is an activity to transfer knowledge from the man to other people with the materials, and use the approach, method or technique. (Brown, 1987)"teaching is showing or helping 
someone to do something, giving instruction, guiding in this study of something, providing with the knowledge causing to know or understand." And usually the man is called as the teacher. Teaching can not defined apart from learning. According to (Brown, 2007) teaching is "guiding and facilitating learning, enabling the learner to learn, setting the conditions for learning." In the teaching process the teacher guide learner to learn, the teacher explain the material easily understanable.

Vocabulary is very important in English, because student can understand the meaning of the word. (Hiebert, E.H \& Kamil, 2005) state,"vocabulary is a set of words for which an individual can assign meanings when listening or reading". Therefore, that is very important for student know a lot of vocabularies. So if the teacher want to make his/her explanation more understand, she/he needs to implement a good method in teaching vocabulary. There are some methods for teaching vocabulary such as grammar translation method, direct method, audio lingual method, silent way, TPR, CLT and so on. In direct method, human learn vocabulary or language directly, whereby "Direct method is a method of teaching a foreign language, especially a modern language through conversation, discussion and reading in the language itself, without translation and the study of formal grammar. The first words are though by pointing to objects, pictures or by performing action" (Patel, M.E \& Jain, 2008). Therefore, direct method is called natural method and this method helps learners to enjoy the language.

\section{METHOD}

The researchers used quantitative research design. According to (McMilan, J.H \& Schumancher, 2001) quantitative research design refers to plan choosing subject, data collection technique, procedures for gathering and procedures for implementing treatment. In this research the researchers used experimental method "experiments are simply a way of learning something by varying some condition and observing the effect on something else. In other words, we change something and watching for the effect"(McMilan, J.H \& Schumancher, 2001) To know the effect from learning process through observe the researchers use one group pretest-posttest design. According to (McMilan, J.H \& Schumancher, 2001)in the one group pretest-posttest design a single group of subjects is given a pretest $(\mathrm{O})$, then the treatment $(\mathrm{X})$, and then the posttest $(\mathrm{O})$. The pretest and posttest are the same, just given at different times. The result that is examined is a change from pretest to posttest. This design popularized as the so called pretest-posttest design.

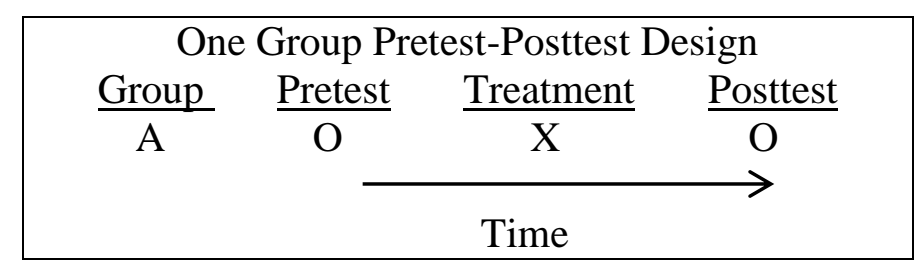

\section{RESULTS AND DISCUSSION}

\section{Results}

The pretest was conducted on March 2nd, 2018 at the seventh grade of MTs. Negeri Sukasari Cimahi to find out students' initial score in vocabulary mastery. The pretest was conducted before the students' received the treatment. Meanwhile the posttest was taken on March 24th, 2018 after the students' got the pretest and treatments. The data were already collected based 
on the pretest and the posttest. The data as the result of the pretest and posttest were analyzed and described in table 1.

Table 1. pretest and posttest students' score

\begin{tabular}{|c|c|c|c|}
\hline No & Name & Score pretest & Score posttest \\
\hline 1. & Student 1 & 75 & 90 \\
\hline 2. & Student 2 & 60 & 90 \\
\hline 3. & Student 3 & 85 & 90 \\
\hline 4. & Student 4 & 55 & 100 \\
\hline 5. & Student 5 & 75 & 80 \\
\hline 6. & Student 6 & 85 & 95 \\
\hline 7. & Student 7 & 80 & 100 \\
\hline 8. & Student 8 & 70 & 100 \\
\hline 9. & Student 9 & 65 & 85 \\
\hline 10. & Student 10 & 85 & 95 \\
\hline 11. & Student 11 & 50 & 90 \\
\hline 12. & Student 12 & 65 & 85 \\
\hline 13. & Student 13 & 85 & 90 \\
\hline 14. & Student 14 & 75 & 100 \\
\hline 15. & Student 15 & 80 & 90 \\
\hline 16. & Student 16 & 80 & 100 \\
\hline 17. & Student 17 & 55 & 80 \\
\hline 18. & Student 18 & 60 & 90 \\
\hline 19. & Student 19 & 75 & 85 \\
\hline 20. & Student 20 & 85 & 90 \\
\hline 21. & Student 21 & 75 & 90 \\
\hline 22. & Student 22 & 85 & 95 \\
\hline 23. & Student 23 & 80 & 100 \\
\hline 24. & Student 24 & 80 & 80 \\
\hline 25. & Student 25 & 90 & 100 \\
\hline 26. & Student 26 & 80 & 90 \\
\hline 27. & Student 27 & 50 & 90 \\
\hline 28. & Student 28 & 55 & 85 \\
\hline 29. & Student 29 & 50 & 85 \\
\hline 30. & Student 30 & 45 & 55 \\
\hline 31. & Student 31 & 85 & 85 \\
\hline \multicolumn{2}{|c|}{ Total } & 2220 & 2780 \\
\hline \multicolumn{2}{|c|}{ Score mean } & 71.61 & 89.68 \\
\hline
\end{tabular}

Normality test

The result of the normality test was from the average of pretest and posttest data. To find out whether the data is normal or not the writer used SPSS 23 program. The results describe in table below: 
Table 2. Descriptive statistic

Descriptives

\begin{tabular}{|c|c|c|c|}
\hline & & Statistic & Std. Error \\
\hline \multirow[t]{13}{*}{ Pretest } & Mean & 71,61 & 2,403 \\
\hline & \multirow[t]{2}{*}{ 95\% Confidence Interval for Mean } & 66,71 & \\
\hline & & 76,52 & \\
\hline & $5 \%$ Trimmed Mean & 72,07 & \\
\hline & Median & 75,00 & \\
\hline & Variance & 178,978 & \\
\hline & Std. Deviation & 13,378 & \\
\hline & Minimum & 45 & \\
\hline & Maximum & 90 & \\
\hline & Range & 45 & \\
\hline & Interquartile Range & 25 & \\
\hline & Skewness &,- 593 &, 421 \\
\hline & Kurtosis & $-1,044$ & ,821 \\
\hline \multirow[t]{13}{*}{ Postest } & Mean & 89,68 & 1,622 \\
\hline & \multirow[t]{2}{*}{ 95\% Confidence Interval for Mean } & 86,36 & \\
\hline & & 92,99 & \\
\hline & $5 \%$ Trimmed Mean & 90,54 & \\
\hline & Median & 90,00 & \\
\hline & Variance & 81,559 & \\
\hline & Std. Deviation & 9,031 & \\
\hline & Minimum & 55 & \\
\hline & Maximum & 100 & \\
\hline & Range & 45 & \\
\hline & Interquartile Range & 10 & \\
\hline & Skewness & $-1,784$ & , 421 \\
\hline & Kurtosis & 6,208 &, 821 \\
\hline
\end{tabular}

Based on the table above, mean of the pretest is 71.61 and mean of the posttest is 89.64 .

\section{Table 3. Test of Normality Statistic}

Tests of Normality

\begin{tabular}{|l|l|l|l|l|l|l|}
\hline & \multicolumn{3}{l|}{ Kolmogorov-Smirnov ${ }^{\mathrm{a}}$} & \multicolumn{4}{l|}{ Shapiro-Wilk } \\
\cline { 2 - 7 } & Statistic & Df & Sig. & Statistic & Df & Sig. \\
\hline Pretest &, 213 & 31 &, 001 &, 887 & 31 &, 004 \\
Postest &, 192 & 31 &, 005 &, 812 & 31 &, 000 \\
\hline
\end{tabular}

a. Lilliefors Significance Correction

Based on the table above, the data were not normally distributed. It can be seen on the sign in Kolmogorov-Smirnov column. If the result $>0.05$ it means the data was normal, however if the result was $<0.05$ it means the data was not normal. In the table above significant values pretest 
$=0.01$, and significant values posttest $=0.05$, because the data were not normal, so the researchers analyzed them through non- parametric test.

Table 4. The Result Non-parametric used Wilcoxon Sign Ranks Statistics Test

Ranks

\begin{tabular}{|ll|l|l|l|}
\hline & & N & Mean Rank & Sum of Ranks \\
\hline postest - pretest & Negative Ranks & $0^{\mathrm{a}}$ &, 00 &, 00 \\
& Positive Ranks & $29^{\mathrm{b}}$ & 15,00 & 435,00 \\
& Ties & $2^{\mathrm{c}}$ & & \\
& Total & 31 & & \\
& & & & \\
\hline
\end{tabular}

a. postest < pretest

b. postest $>$ pretest

c. postest $=$ pretest

Table 5. Test Statistics

Test Statistics ${ }^{a}$

\begin{tabular}{|l|l|}
\hline & postest - pretest \\
\hline$Z$ & $-4,721^{\mathrm{b}}$ \\
Asymp. Sig. (2-tailed) &, 000 \\
\hline
\end{tabular}

a. Wilcoxon Signed Ranks Test

b. Based on negative ranks.

After the researchers calculated the data by using SPSS program, the researchers got the tables above. Asymp.Sig. (2-tailed) in test statistic column, if the value is higher than 0.05 the Null Hypothesis (Ho) was accepted, however if the value lower than 0.05 the Null Hypothesis (Ho) was rejected. Meanwhile, after the writer calculated the data by using Wilcoxon test, Asymp.Sig. $(2$-tailed) $=0.000$ the data was normal it means the Null hypothesis $(\mathrm{Ho})$ is rejected.

\section{Discussion}

After the researchers conducted the research in MTs. Negeri Sukasari Cimahi at the seventh grade, the researchers found the following findings on teaching vocabulary using direct method. As described in earlier chapter, the mean of posttest was bigger than mean pretest. The sum of positive ranks was bigger than the sum of negative ranks. Ho is rejected because Asymp.Sig. ( 2 tailed $=0.000$ ) was smaller than 0.05 , and the hypothesis was supported. In other word, teaching vocabulary using direct method was effective. Therefore teaching vocabulary using direct method can increase students' vocabulary mastery in MTs. Negeri Cimahi at the seventh grade.

\section{CONCLUSION}

After the writer conducted the research in MTs. Negeri Sukasari Cimahi at seventh grade, the writer found the following findings on the teaching vocabulary using direct method.

Direct method is an effective method that built vocabulary mastery in teaching process. It is showed from the mean of the students score between pretest $=71.61$ and posttest $=89.68$ data 
based on the table 4.3. Based on the results the data analysis of the research, it showed from the calculated used Wilcoxon's formula, null hypothesis (Ho) rejected based on the table 4.6, Asymp.Sig. $(2$ tailed $=0.000)$ was smaller less than 0.05 it is mean the alternative hypothesis (Ha) was supported.

\section{ACKNOWLEDGMENTS}

Alhamdulillahirabil'alamin, praise to ALLAH SWT who has enabled the researchers to finish this journal. Peace and solutions are always for Rasulullah SAW. And thank you to IKIP Siliwangi Bandung especially English Education Study Program, and also thank you so much for Mr. Efransyah as the best supervisior. This journal is far from perfect, but it is expected that it will be useful not only for the researchers, but also for the readers. For this reason, the suggestion and critics are welcomed.

\section{REFERENCES}

Brown, H. D. (1987). Understanding Research in Second Language Learning: A Teacher's Guide to Statistic and Research Design. Cambridge University Press.

Brown, H. D. (2007). Principles of Language Learning and Teaching. New York: Longman. Hiebert, E.H \& Kamil, M. (2005) Teaching and Learning Vocabulary Bringing Research to.

Hiebert, E.H \& Kamil, M. (2005). Teaching and Learning Vocabulary Bringing Research to Practice. United States: Lawrence Erlbaum Associates.

Kaswan \& Suprijadi, D. (2011). Language in Society. bandung: STKIP Siliwangi. McMilan, J.H \& Schumancher, S. (2001). ). Research in Education. New York: Longman.

Patel, M.E \& Jain, P. M. (2008). English Language Teaching (Method, tools and Techniques). Sunrise Publisher \& Distributors. 